\title{
TANGGUNG JAWAB PEJABAT PEMBUAT AKTA TANAH (PPAT) TERHADAP PENDAFTARAN PERALIHAN HAK ATAS TANAH YANG MENJADI OBJEK SENGKETA
}

\author{
Oleh : \\ Ida Ayu Wulan Rismayanthi* \\ NIM 1292461012 \\ Program Magister Kenotariatan Universitas Udayana \\ e-mail : wulan.idaayu@gmail.com \\ Pembimbing I : Prof. Dr. I Gusti Ngurah Wairocana, SH.,MH.** \\ Pembimbing II : I Made Pria Dharsana, SH.,M.Hum.***
}

\begin{abstract}
The Land Deed Official (the PPAT) is a public official who is granted part of the authorities by the State in the implementation of land registration, by making the land certificate as the basis for land registration. The Agrarian Office may turn down the registration of the land rights in the event of any recording in the land registry books of the land rights which become the object of dispute. Based on Article 45 of the Government Regulation Number 24 of 1997 that there is a legal ambiguity on the return of the files in the form of certificate, title deed and other related documents. According to Article 55 of the Head of National Land Agency number 1 of 2006, the PPAT is personally responsible for the execution of the task and his/her authority, in every act making. There is no clear arrangement regarding the responsibility of PPAT on the registration of the conveyance of the land which becomes the object of dispute. Such provisions result in legal issues about the legal consequences and the responsibility of PPAT on the registration of the conveyance of the land which becomes the object of dispute

The type of research used in this thesis is a normative legal research as the result of the presence of the ambiguity and the vacuum of norms. The legal materials were collected by the techniques of library research and the card system. The descriptive, interpretative and argumentative theories as well as associated with laws that relevant to the issues were used to analyze the legal materials.

The results showed that the Agrarian Office turns down and returns the documents to the PPAT as the legal consequence of the conveyance of land which becomes the object of dispute. The legal consequences of the deed made before the PPAT remains authentic during a blocking of certificate. The responsibility of the PPAT is in accordance with his/her position, in keeping the deed, certificate along with the relevant documents at the time of the restitution by the Agrarian Office. PPAT shall be mandatory as an intermediary to keep the documents that are being returned at the time of confiscation by a court or at the revocation of blocking by the applicant.

Keywords: The responsibility, the PPAT, the Registration, the Conveyance, the Land Rights, the Land Dispute.

* Mahasiswa Program Studi Magister Kenotariatan T.A 2012/2013

**Pembimbing I

*** Pembimbing II
\end{abstract}

\section{PENDAHULUAN}

\subsection{Latar Belakang Masalah}

Indonesia adalah negara yang bercorak agraris. Hukum yang mengatur mengenai bumi, air dan ruang angkasa adalah hukum agraria. Dengan berlakunya Undang-Undang Nomor 5 Tahun 1960 tentang Peraturan dasar PokokPokok Agraria (selanjutnya disebut UUPA) terciptalah suatu kesatuan hukum dalam hukum
Agraria di Indonesia. Menurut Pasal 19 ayat (1) UUPA, untuk menjamin kepastian hukum oleh pemerintah diadakan kegiatan pendaftaran tanah di seluruh wilayah Republik Indonesia. Pelaksanaan kegiatan pendaftaran tanah diatur dalam Peraturan Pemerintah Republik Indonesia Nomor 10 Tahun 1961 Tentang Pendaftaran Tanah (selanjutnya disebut PP No. 10 tahun 1961) dan telah diganti menjadi 
Peraturan Pemerintah Republik Indonesia Nomor 24 Tahun 1997 Tentang Pendaftaran Tanah (selanjutnya disebut PP No. 24 tahun 1997).

Dalam hal mengurus administrasi pertanahan, ditunjuk instansi pemerintah yang diberikan kewenangan yaitu Badan Pertanahan Nasional Republik Indonesia (selanjutnya disebut BPN). Kantor pertanahan adalah unit kerja BPN di setiap wilayah kabupaten atau kota. Dalam melaksanakan tugasnya, kantor pertanahan dibantu oleh Pejabat Pembuat Akta Tanah (selanjutnya disebut PPAT) yang bertugas pokok melaksanakan sebagian kegiatan pendaftaran tanah dengan membuat akta sebagai alat bukti dan dasar pendaftaran tanah.

Sebelum pembuatan akta, PPAT wajib melakukan pemeriksaan kesesuaian sertipikat dengan data dalam buku tanah pada kantor pertanahan. Apabila pada saat pendaftaran peralihan hak atas tanah, hak atas tanah menjadi objek sengketa, pihak-pihak yang berkepentingan dapat mengajukan gugatan ke pengadilan. Dalam rangka kelancaran proses persidangan di pengadilan, para pihak yang berkepentingan dapat meminta dilakukan pencatatan dalam buku tanah sesuai Pasal 126 ayat (1) Peraturan Kepala Badan Pertanahan Nasional Republik Indonesia Nomor 8 Tahun 2012 tentang Perubahan Atas Peraturan Menteri Agraria/Kepala Badan Pertanahan Nasional Nomor 3 Tahun 1997 tentang Ketentuan Pelaksanaan Peraturan Pemerintah
Nomor 24 Tahun 1997 tentang Pendaftaran Tanah (selanjutnya disebut Peraturan Kepala BPN No. 8 Tahun 2012).

Kantor pertanahan dapat menolak melakukan pendaftaran peralihan hak atas tanah. Pasal 45 ayat (3) PP No. 24 Tahun 1997 menentukan "surat penolakan disampaikan kepada yang berkepentingan, disertai adanya pengembalian berkas permohonannya, dengan salinan kepada PPAT atau Kepala Kantor Lelang yang bersangkutan." Terdapat ketidakjelasan kepada siapa berkas permohonan tersebut dikembalikan oleh kantor pertanahan.

Menurut Pasal 55 Peraturan Kepala Badan Pertanahan Nasional Republik Indonesia Nomor 1 tahun 2006 Tentang Ketentuan Pelaksanaan Peraturan Pemerintah No. 37 Tahun 1998 Tentang Peraturan Jabatan Pejabat Pembuat Akta Tanah (selanjutnya disebut Peraturan Kepala BPN No. 1 Tahun 2006) ditentukan "PPAT bertanggung jawab secara pribadi atas pelaksanaan tugas dan jabatannya dalam setiap pembuatan akta." Muncul permasalahan pada saat pendaftaran peralihan hak atas tanah dilakukan pencatatan dalam buku tanah karena hak atas tanah menjadi objek sengketa sehingga adanya pengembalian berkas-berkas atau dokumen-dokumen yang digunakan dalam pendaftaran tersebut oleh kantor pertanahan.

Tidak terdapatnya pengaturan mengenai tanggung jawab PPAT terhadap pengembalian dokumen oleh kantor pertanahan tersebut. Berdasarkan uraian tersebut, maka penelitian ini beranjak dari adanya kekaburan dan kekosongan norma, dengan judul “Tanggung Jawab 
Pejabat Pembuat Akta Tanah (PPAT)

Terhadap Pendaftaran Peralihan Hak Atas Tanah Yang Menjadi Objek Sengketa."

\subsection{Rumusan Masalah}

1. Bagaimana akibat hukum terhadap pendaftaran peralihan hak atas tanah dengan akta PPAT yang menjadi objek sengketa?

2. Bagaimana tanggung jawab PPAT terhadap pendaftaran peralihan hak atas tanah yang menjadi objek sengketa?

\subsection{Landasan Teoritis}

\subsubsection{Teori Kewenangan}

Pengertian wewenang dalam bahasa Inggris adalah authority sedangkan dalam bahasa Belanda disebut bevoegdheid. Wewenang atau kewenangan merupakan suatu tindakan hukum yang diatur dan diberikan kepada suatu jabatan berdasarkan peraturan perundang-undangan yang berlaku yang mengatur jabatan yang bersangkutan. ${ }^{1}$ Menurut Ridwan HR yang dikutip dari pendapat H.D Van Wijk/Willem Konijnenbelt sumber kewenangan ada 3 (tiga), yaitu :

a. Attributie toekenning van een bestuursbevoegheid door een wetgever aan een bestuursorgaan (atribusi adalah pemberian wewenang pemerintahan oleh pembuat undang-undang kepada organ pemerintahan);

b. Delegatie : overdracht van een bevoegheid van het ene bestuurorgaan aan een ander (delegasi adalah pelimpahan weweang pemerintahan dari satu organ pemerintahan kepada organ pemerintahan lainnya);

c. Mandaat : een bestuurorgaan laat zijn bevoegheid namens hem uitoefenen door een ander (mandat terjadi ketika organ

${ }^{1}$ Habib Adjie, 2008, Hukum Notaris Indonesia, Tafsir Tematik Terhadap UU No. 30 Tahun 2004 tentang Jabatan Notaris, Refika Aditama, Bandung, hal. 77. pmerintahan mengizinkan kewenangannya dijalankan oleh organ lain atas namanya). ${ }^{2}$

Teori kewenangan untuk menganalisis mengenai kewenangan PPAT yang diperoleh secara atribusi dalam membuat akta sebagai dasar pendaftaran tanah.

\subsubsection{Teori Pertanggungjawaban}

Setiap kewenangan sangat erat kaitannya dengan kewajiban dan tanggung jawab. Mengenai persoalan pertanggungjawaban pejabat menurut Kranenburg dan Vegtig ada dua teori yang melandasi. Teori Fautes Personalles, bahwa kerugian terhadap pihak ketiga dibebankan kepada pejabat yang karena tindakannya itu telah menimbulkan kerugian. Beban tanggung jawab ditujukan pada manusia selaku pribadi dan Teori Fautes de Services, bahwa kerugian terhadap pihak ketiga dibebankan pada instansi dari pejabat yang bersangkutan. Menurut teori ini tanggung jawab dibebankan kepada jabatan. ${ }^{3}$ Teori pertanggungjawaban untuk menganalisis tanggung jawab PPAT berdasarkan kewenangan yang dimilikinya terhadap pendaftaran peralihan hak atas tanah yang menjadi objek sengketa.

\subsubsection{Teori Keabsahan}

Suatu keputusan yang tidak memenuhi persyaratan, menurut hukum ketetapan atau keputusan tersebut menjadi "tidak sah" yang berakibat hukum menjadi "batal" (nietig).

${ }^{2}$ Ridwan HR, 2007, Hukum Administrasi Negara, PT RajaGrafindo Persada, Jakarta. hal 104-105.

${ }^{3}$ Shidarta, 2000, Hukum Perlindungan Konsumen, Grasindo, Jakarta, hal. 335-337.

${ }^{4}$ Ardiansyah, 2012, "Tolak Ukur Keabsahan Tindak Pemerintahan dan Keputusan Tata Usaha Negara", http://ardianlovenajlalita.wordpress.com/tolokukur-keabsahan-tindak-pemerintahan-dan- 
Menurut Van der Pot yang dikutip oleh Philipus

M. Hadjon dalam bukunya yang berjudul "Pengertian-pengertian Dasar Tentang Tindak Pemerintahan", ada 4 syarat yang harus dipenuhi agar ketetapan administrasi sebagai ketetapan sah, yaitu :

1. bevoedgheid (kewenangan) organ administrasi yang membuat keputusan.

2. geen juridische gebreken in de wilsvorming (tidak ada kekurangan yuridis dalam pembentukan kehendak).

3. vorm dan procedure yakni keputusan dituangkan dalam bentuk yang telah ditetapkan dan dibuat menurut tata cara yang telah ditetapkan.

4. Isi dan tujuan keputusan sesuai dengan isi dan tujuan peraturan dasar.

Philipus M. Hadjon menyatakan bahwa ada 3 (tiga) aspek adalah ketiga yang merupakan landasan hukum untuk dapat dikatakan suatu ketetapan atau keputusan sah yaitu aspek wewenang, aspek prosedur dan aspek substansi. ${ }^{6}$ Teori keabsahan ini untuk mengkaji mengenai keabsahan akta yang dibuat dihadapan PPAT yang digunakan sebagai dasar pendaftaran tanah terkait dengan adanya pemblokiran sertipikat.

\subsubsection{Teori Kepastian Hukum}

Menurut Gustav Radbruch, ada tiga tujuan dari hukum yaitu keadilan, kemanfaatan dan kepastian hukum. Teori kepastian hukum mengandung dua pengertian. Pertama, adanya aturan yang bersifat umum yang membuat individu mengetahui dan memahami perbuatanperbuatan apa yang boleh dan tidak boleh dilakukan. Kedua, adanya keamanan hukum berupa jaminan kepastian hukum bagi individu dari kesewenangan pemerintah karena adanya aturan hukum yang bersifat umum sehingga individu dapat mengetahui apa yang boleh

keputusan-tata-usaha-negara/, diakses pada tanggal 05 Maret 2014.

${ }^{5}$ Boedi Djatmiko Hadiatmodjo, 2010, "Tanah dan Hukum Tanah", http://sertifikattanah.blogspot.com/, diakses pada tanggal 21 Pebruari 2014.

${ }^{6}$ Ardiansyah, Loc.cit. dilakukan oleh Negara terhadap individu. ${ }^{7}$ Teori ini untuk menganalisis mengenai kepastian hukum pendaftaran peralihan hak atas tanah yang aktanya dibuat dihadapan PPAT.

\subsection{Tujuan Penelitian}

\subsubsection{Tujuan Umum}

Secara umum, penulisan karya ilmiah ini bertujuan untuk melaksanakan Tri Dharma Perguruan Tinggi, khususnya pada bidang penelitian mengenai suatu permasalahan hukum, terkait dengan tanggung jawab PPAT terhadap pendaftaran peralihan hak atas tanah yang menjadi objek sengketa. Penelitian ini juga bertujuan untuk mengembangkan ilmu pengetahuan hukum terkait peraturan di bidang pertanahan.

\subsubsection{Tujuan Khusus}

1. Untuk mengetahui dan menganalisis mengenai akibat hukum terhadap pendaftaran peralihan hak atas tanah dengan akta PPAT yang menjadi objek sengketa.

2. Untuk mengetahui dan menganalisis mengenai tanggung jawab PPAT terhadap pendaftaran peralihan hak atas tanah yang menjadi objek sengketa.

\section{METODE PENELITIAN}

\subsection{Jenis Penelitian}

Jenis penelitian yang digunakan adalah penelitian hukum normatif,

${ }^{7}$ Peter Mahmud Marzuki, 2008, Pengantar Ilmu Hukum, Kencana Predana Media Group, Jakarta, (selanjutnya disingkat Peter Mahmud Marzuki I), hal. 158. 
yaitu penelitian hukum yang dilakukan dengan cara mengkaji bahan-bahan yang berasal dari berbagai peraturan perundang-undangan dan bahan-bahan lain dari berbagai literatur yang terkait dengan permasalahan yang akan dibahas. ${ }^{8}$ Penelitian ini beranjak dari adanya kekaburan norma dalam Pasal 45 ayat (3) PP no. 24 tahun 1997 mengenai pengembalian berkas oleh Kantor Pertanahan terkait dengan adanya hak atas tanah yang menjadi objek sengketa sehingga dilakukan pencatatan dalam buku tanah dan adanya kekosongan norma mengenai tanggung jawab PPAT terhadap pendaftaran peralihan hak atas tanah karena hanya terdapat pasal yang mengatur mengenai tanggung jawab PPAT secara pribadi terhadap akta yang dibuatnya sebagaimana dinyatakan dalam Pasal 55 Peraturan Kepala BPN No. 1 tahun 2006.

\subsection{Jenis Pendekatan}

Dalam penelitian ini digunakan 3 (tiga) pendekatan yaitu pendekatan Perundangundangan (statute approach) yang dilakukan dengan menelaah semua undang-undang dan regulasi yang bersangkut paut dengan isu hukum yang sedang ditangani, ${ }^{9}$ Pendekatan konsep (conceptual approach) dilakukan dengan beranjak dari peraturan perundangundangan yang ada, dan merujuk pada konsepkonsep hukum, ${ }^{10}$ dan pendekatan kasus (case approach) yaitu pendekatan berdasarkan kasuskasus yang terkait dengan isu hukum yang akan dikaji.

${ }^{8}$ Soerjono Soekanto dan Sri Mamudji, 2007, Penelitian Hukum Normatif : Suatu Tinjauan Singkat, PT. Raja Grafindo Persada, Jakarta, hal. 13.

${ }^{9}$ Ibid.

${ }^{10}$ Johnny Ibrahim, 2005, Teori dan Metodologi Penelitian Hukum Normatif, Bayumedia, Surabaya, hal.306.

\subsection{Sumber Bahan Hukum}

a. Bahan hukum primer adalah bahan-bahan hukum yang mengikat. ${ }^{11}$ Bahan hukum primer berupa peraturan perundangundangan yang terkait dengan permasalahan, antara lain :

1. Undang-Undang Dasar Negara Republik Indonesia 1945.

2. Kitab Undang-undang Hukum Perdata.

3. Undang-Undang Republik Indonesia Nomor 5 Tahun 1960 tentang Peraturan Dasar Pokok-Pokok Agraria

4. Peraturan Pemerintah Republik Indonesia Nomor 24 Tahun 1997 tentang Pendaftaran Tanah,

5. Peraturan Pemerintah Republik Indonesia Nomor 37 tahun 1998 tentang Peraturan Pejabat Pembuat Akta Tanah,

6. Peraturan Presiden Republik Indonesia Nomor 10 tahun 2006 tentang Badan Pertanahan Nasional.

7. Peraturan Kepala Badan Pertanahan Nasional Nomor 1 Tahun 2006 Tentang Ketentuan Pelaksanaan Peraturan Pemerintah No. 37 Tahun 1998 Tentang Peraturan Jabatan Pejabat Pembuat Akta Tanah.

8. Peraturan Kepala Badan Pertanahan Nasional Nomor 8 tahun 2012 tenttang Perubahan Atas Peraturan Menteri Agraria/Kepala Badan Pertanahan Nasional Nomor 3 tahun 1997 tentang Ketentuan Pelaksanaan Peraturan Pemerintah Nomor 2 Tahun 1997 tentang Pendaftaran Tanah.

b. Bahan hukum sekunder merupakan bahan hukum yang memberikan penjelasan mengenai bahan hukum primer. $^{12}$ Bahan

${ }^{11}$ Bambang Sunggono, 2010, Metodelogi Penelitian Hukum, Rajawali Pers, Jakarta, hal. 113. ${ }^{12}$ Ibid, hal. 114. 
hukum sekunder yang digunakan berupa literatur-literatur berupa buku-buku yang berkaitan dengan permasalahan.

c. Bahan hukum tertier yakni bahan-bahan hukum yang memberikan petunjuk maupun penjelasan terhadap bahan hukum primer dan sekunder. ${ }^{13}$ Bahan hukum tertier yang digunakan adalah artikel-artikel dari internet.

\subsection{Teknik Pengumpulan Bahan Hukum}

Teknik pengumpulan bahan hukum dalam penelitian ini adalah dengan melakukan studi kepustakaan, yaitu mengumpulkan semua bahan hukum yang terkait untuk memperoleh data yang objektif dan akurat yang secara khusus dilakukan dengan menggunakan sistem kartu (card system). Sistem kartu ini menggunakan kartu kutipan yang digunakan untuk mencatat hal-hal penting yang merupakan bahan hukum yang relevan dengan permasalahan yang dibahas dalam penulisan ini, yang kemudian dikutip beserta sumber.

\subsection{Teknik Analisis Bahan Hukum.}

Langkah pertama yang dipergunakan dalam menganalisis dalam penelitian ini adalah teknik deskriptif sebagai teknik dasar analisis. Deskriptif berarti menguraikan apa adanya terhadap suatu kondisi atau posisi dari proposisi-proposisi hukum atau non hukum. Kemudian teknik interpretasi atau penafsiran untuk menganalisa norma-norma hukum yang tidak jelas perumusannya. Teknik interpretasi memberikan penjelasan gamblang tentang teks undang undang, agar

${ }^{13}$ Ibid. ruang lingkup kaidah dalam undang undang tersebut dapat diterapkan pada peristiwa hukum tertentu. ${ }^{14}$ Teknik interprestasi yang dipergunakan dalam penelitian ini adalah interpretasi gramatikal atau tata bahasa dan interpretasi sistematis. Selanjutnya digunakan teknik argumentasi untuk mengemukakan pendapat-pendapat terhadap permasalahan yang telah diteliti.

III. TINJAUAN UMUM TENTANG PPAT, PENDAFTARAN TANAH, PERALIHAN HAK ATAS TANAH DAN SENGKETA HAK ATAS TANAH

\subsection{Tinjauan Umum Tentang PPAT}

Pengertian PPAT tidak hanya dimuat dalam satu peraturan perundang-undangan saja, namun dimuat dalam beberapa peraturan perundang-undangan. Menurut Pasal 1 angka (1) PP No. 37 Tahun 1998, "Pejabat Pembuat Akta Tanah adalah pejabat umum yang diberi kewenangan untuk membuat akta autentik mengenai perbuatan hukum tertentu mengenai hak atas tanah atau Hak Milik Atas Satuan Rumah Susun."

Tugas pokok PPAT dalam membantu pelaksanaan pendaftaran tanah oleh Kepala Kantor Pertanahan Kabupaten atau Kota ditetapkan dalam Pasal 2 PP No. 37 Tahun 1998, yaitu melaksanakan sebagian kegiatan pendaftaran tanah dengan membuat akta sebagai bukti telah dilakukannya perbuatan hukum tertentu mengenai hak atas tanah atau Hak Milik Atas Satuan Rumah Susun, yang akan dijadikan dasar bagi pendaftaran

${ }^{14}$ Ahmad Rifai, 2010, Penemuan Hukum Oleh Hakim Dalam Perspektif Hukum Progresif, Sinar Grafika, Jakarta, hal. 61. 
perubahan data pendaftaran tanah yang diakibatkan oleh perbuatan hukum itu. Mengenai kewenangan yang diberikan kepada PPAT diatur dalam Pasal 3 PP No. 37 Tahun 1998 yaitu membuat akta otentik mengenai semua perbuatan hukum yang terletak di dalam daerah kerjanya.

PPAT memiliki kewajiban sebagaimana telah ditentukan dalam Pasal 45 Peraturan Kepala BPN No. 1 Tahun 2006. Sedangkan mengenai larangan terhadap PPAT Dalam ketentuan Pasal 30 ayat (1) Peraturan Kepala BPN No. 1 Tahun 2006 juncto Pasal 23 ayat (1) juncto Pasal 30 ayat (1) juncto Pasal 32 ayat (3) PP No. 37 Tahun 1998 telah ditentukan mengenai larangan-larangan PPAT. PPAT tidak dapat merangkap jabatan atau profesi sebagai pegawai negeri, pegawai Negara (BUMN), badan Usaha Milik Daerah (BUMD) dan jabatan-jabatan lain yang dilarang dalam peraturan perundang-undangan.

Akta PPAT adalah akta yang dibuat oleh PPAT sebagai bukti telah dilaksanakannya perbuatan hukum tertentu mengenai hak atas tanah atau Hak Milik Atas Satuan Rumah Susun. Sebelum berlakunya Peraturan Kepala BPN No. 8 Tahun 2012, PPAT dalam membuat akta ditentukan dengan cara mengisi blanko yang diperoleh dari BPN. Setelah berlakunya Peraturan Kepala BPN No. 8 tahun 2012, PPAT dapat membuat aktanya sendiri tanpa mengisi blanko namun tetap dengan format yang diberikan oleh BPN sebagaimana lampiran Peraturan Kepala BPN No. 8 Tahun 2012 tersebut. Akta PPAT adalah akta otentik, hal ini ditegaskan dalam Pasal 1 ayat (1) dan Pasal 3 ayat (1) PP No. 37 Tahun 1998.

\subsection{Tinajauan Umum Tentang} Pendaftaran Tanah dan Peralihan Hak Atas Tanah

Hak atas tanah adalah hak yang memberi wewenang kepada yang mempunyai hak untuk menggunakan atau mengambil manfaat dari tanah yang dihakinya. Hak-hak atas tanah yang disebutkan dalam Pasal 4 ayat (1) UUPA dijabarkan dalam Pasal 16 ayat (1) UUPA, yaitu Hak Milik, Hak Guna Usaha, Hak Pakai, Hak Sewa untuk bangunan, Hak Membuka Tanah, Hak Memungut Hasil Hutan, dan Hakhak lain yang tidak termasuk dalam hak-hak tersebut diatas tanah yang akan ditetapkan dengan undangundang, serta hak-hak yang sifatnya sementara. Hak-hak atas tanah yang bersifat sementara dalam Pasal 53 UUPA, yaitu Hak Gadai, Hak Usaha bagi Hasil, Hak Menumpang dan Hak Sewa Tanah Pertanian. ${ }^{15}$

Menurut Boedi Harsono yang dimaksud dengan pendaftaran tanah adalah : "Suatu rangkaian kegiatan yang dilakukan secara teratur, terus menerus untuk mengumpulkan, menghimpun dan menyajikan mengenai semua tanah atau tanahtanah tertentu yang ada di suatu wilayah." 16 Dalam Pasal 1 ayat 1 PP No. 24 Tahun 1997 terdapat pengertian pendaftaran tanah yaitu

${ }^{15}$ Urip Santoso, 2010, Pendaftaran dan Peralihan Hak atas Tanah, Kencana Predana Media Group, Jakarta hal. 50-51

${ }^{16}$ Boedi Harsono, 1978, Beberapa Analisis Tentang Hukum Agraria II, Esa Studi Klub, Jakarta, Hal. 9. 
yang dimaksud dengan pendaftaran tanah adalah :

"Rangkaian kegiatan yang dilakukan oleh pemerintah secara terusmenerus berkesinambungan dan teratur meliputi pengumpulan, pengolahan, pembukuan dan penyajian serta pemeliharan data fisik dan data yuridis, dalam bentuk peta dan daftar mengenai bidang-bidang tanah dan satuansatuan rumah susun termasuk pemberian surat tanda bukti haknya bagi tanah yang sudah ada hak milik atas satuan rumah susun serta hak-hak yang membebaninya."

Tujuan penyelenggaraan pendaftaran tanah adalah untuk memberikan kepastian hukum dan perlindungan hukum kepada para pemegang hak atas suatu bidang tanah, satuan rumah susun dan hak-hak lain yang terdaftar agar dengan mudah dapat membuktikan dirinya sebagai pemegang hak yang bersangkutan. Menurut Soedikno Mertokusumo, dalam pendaftaran tanah dikenal 2 macam asas yaitu asas specialiteit dan asas Openbaarheid. ${ }^{17} \quad$ Sistem pendafataran tanah yang dianut oleh Negara Indonesia adalah sistem pendaftaran hak (registration of titles). Sedangkan sistem publikasi yang digunakan yaitu sistem negatif mengandung unsur positif karena dalam pendaftaran haknya, Indonesia menggunakan akta sebagai alat bukti telah dilakukannya perbuatan hukum tertentu mengenai hak atas tanah. Akta yang dibuat dihadapan PPAT adalah salah satu subsistem pendaftaran hak. Dalam sistem positif, daftar umumnya mempunyai kekuatan bukti, maka orang yang terdaftar adalah pemegang hak yang sah. Terdapat dua bentuk

${ }^{17}$ Urip Santoso, Op.cit, hal. 16-17. peralihan hak atas tanah atau hak milik atas satuan rumah susun, yaitu beralih dan dialihkan. Dalam peralihan hak atas tanah berdasarkan jual beli diperlukan akta jual beli dibuat dihadapan PPAT sebagai alat bukti telah dilakukannya peralihan hak atas tanah berdasarkan asas hukum adat yaitu terang dan tunai.

\subsection{Tinjauan Umum Tentang Sengketa Hak Atas Tanah}

Menurut Suyud Margono, timbulnya sengketa hukum tentang tanah bermula dari pengaduan satu pihak tentang keberatan dan tuntutan hukum terhadap status tanah akibat perbuatan hukum yang telah merugikan hak atas tanah dari pihak penggugat dengan harapan dapat memperoleh penyelesaian secara administrasi sesuai dengan ketentuan peraturan yang berlaku. ${ }^{18}$ Materi gugatan dapat berupa tuntutan adanya kepastian hukum mengenai siapa yang berhak, status tanah, bukti-bukti yang menjadi dasar pemberian hak dan sebagainya. ${ }^{19}$

${ }^{18}$ Rusmadi $\quad$ Murad, 1991, Penyelesaian Sengketa Hukum Atas Tanah, Alumni, , Bandung, hal. 22.

${ }^{19}$ Elza Syarief, 2014, Menuntaskan Sengketa Tanah Melalui Pengadilan Khusus Pertanahan, Cetakan Kedua, PT. Gramedia, Jakarta, hal. 174. 
IV. AKIBAT HUKUM TERHADAP PENDAFTARAN PERALIHAN HAK ATAS TANAH DENGAN AKTA PPAT YANG MENJADI OBJEK SENGKETA

\subsection{Proses Peralihan Hak Atas Tanah Berdasarkan Jual Beli Dihadapan PPAT}

Prosedur atau tata cara peralihan hak milik atas tanah berdasarkan jual beli tergantung pada syarat-syarat sahnya jual beli hak milik atas tanah. Untuk kepentingan pendaftaran peralihan hak atas tanah, terdapat dua syarat yang harus dipenuhi, yaitu syarat materiil dan syarat formil. Syarat materiil terkait dengan syarat sahnya perjanjian dan juga syarat sahnya jual beli menurut Hukum Adat yaitu asas terang dan tunai. Syarat formil terkait dengan pendaftarannya, jual beli harus dibuktikan dengan akta PPAT. Ada empat tahapan dalam proses peralihan hak atas tanah berdasarkan jual beli dihadapan PPAT, yaitu :

1. Tahap Persiapan Pembuatan Akta

Ketentuan mengenai tahap persiapan pembuatan akta diatur dalam ketentuan Pasal 97 juncto Pasal 100 Peraturan Kepala BPN No. 8 tahun 2012. Sebelum membuat akta jual beli terhadap peralihan hak atas tanah, PPAT wajib terlebih dahulu melakukan pemeriksaan sertipikat pada Kantor Pertanahan dengan memperlihatkan sertipikat asli. Apabila sertipikat hak atas tanah yang diperiksakan telah sesuai dengan buku tanah di Kantor Pertanahan setempat, maka Kepala Kantor Pertanahan atau pejabat yang ditunjuk membubuhkan cap atau tulisan dengan kalimat : "Telah diperiksa dan sesuai dengan daftar di Kantor Pertanahan" pada halaman perubahan sertipikat asli kemudian diparaf dan diberi tanggal pengecekan.

PPAT membuat akta setelah pemegang hak atas tanah atau hak milik atas satuan rumah susun membuat pernyataan bahwa hak atas tanah atau hak milik atas satuan rumah susun itu tidak sedang disengketakan. Selain pengecekan sertipikat dengan daftar-daftar dalam buku tanah pada Kantor pertanahan setempat. PPAT juga wajib menyampaikan kepada para pihak yaitu calon penjual dan calon pembeli untuk terlebih dahulu membayar pajak yang dibebankan kepadanya. Berdasarkan ketentuan Pasal 39 ayat (1) PP No. 24 Tahun 1997, PPAT dapat menolak untuk membuat akta. PPAT dapat menolak untuk membuat akta apabila salah satu syarat dalam pembuatan akta tidak terpenuhi.

2. Tahap Pelaksanaan Pembuatan Akta Setelah pengecekan sertipikat dan dinyatakan telah sesuai kemudian pajak-pajak telah terbayarkan, maka tahap selanjutnya adalah pembuatan akta PPAT. Akta PPAT dibuat sebanyak dua lembar asli, satu lembar disimpan di kantor PPAT dan satu lembar disampaikan kepada kepala kantor pertanahan setempat untuk keperluan pendaftaran, sedangkan kepada pihak-pihak yang bersangkutan yaitu penjual dan pembeli diberikan salinan aktanya. PPAT wajib membacakan akta kepada para pihak. Dalam pembuatan akta, selain ketentuan-ketentuan yang telah 
disebutkan diatas, PPAT juga harus memperhatikan hal-hal yaitu :

a. Identitas dari para pihak. PPAT harus memeriksa kebenaran formil dari identitas para pihak serta dasar hukum tindakan para pihak.

b. Jangka waktu berakhirnya hak atas tanah yang diperjualbelikan karena jika jangka waktunya berakhir, tanahnya kembali dikuasai oleh Negara.

c. Harga jual beli harus sudah dibayar lunas sebelum akta ditandatangani yang merupakan konsekuensi dari UUPA yang berdasarkan kepada Hukum Adat. Bukti lunas umumnya berupa kwitansi atau bukti transfer bank.

d. Tidak terdapat tunggakan Pajak Bumi dan Bangunan (PBB).

e. Tanah yang diperjualbelikan harus berada dalam wilayah kerja PPAT yang bersangkutan terkait dengan kewenangan PPAT dalam hal pembuatan akta.

3. Tahap Pendaftaran Peralihan Hak Atas Tanah.

Menurut ketentuan Pasal 40 PP No. 24 Tahun 1997, selambatlambatnya 7 (tujuh) hari kerja sejak tanggal ditandatanganinya akta yang bersangkutan, PPAT wajib menyampaikan akta yang dibuatnya berikut dokumen-dokumen yang bersangkutan kepada Kantor Pertanahan untuk didaftar. Kantor pertanahan wajib memberikan tanda penerimaan atas penyerahan permohonan pendaftaran pemindahan hak beserta akta PPAT dan dokumendokumen lain yang dilampirkan yang diterimakan kepada PPAT yang bersangkutan. Pencatatan peralihan hak dalam buku tanah, sertipikat, dan daftar lainnya dilakukan sebagai berikut :

a. Nama pemegang hak lama yaitu penjual di dalam buku tanah dicoret dengan tinta hitam dan dibubuhi paraf kepala kantor pertanahan;

b. Nama atau nama-nama pemegang hak yang baru yaitu pembeli dituliskan pada halaman dan kolom yang ada dalam buku tanahnya dengan dibubuhi tanggal pencatatan, dan kemudian ditandatangani oleh kepala kantor pertanahan setempat atau pejabat lain yang ditunjuk dan cap dinas kantor pertanahan setempat.

4. Tahap Penyerahan Sertipikat Hak Atas Tanah

Setelah proses pendaftaran peralihan hak atas tanah selesai maka Kantor Pertanahan akan menyerahkan kepada PPAT yang bersangkutan untuk disampaikan kepada pemegang hak yang baru. Sertipikat hak atas tanah atau hak milik atas satuan rumah susun yang telah diubah nama pemegang haknya diserahkan kepada pemegang hak atas tanah yang baru. Menurut ketentuan Pasal 31 ayat (3) PP No. 24 tahun 1997, sertifikat hanya boleh diserahkan kepada pihak yang namanya tercantum dalam buku tanah yang bersangkutan sebagai pemegang hak atau kepada pihak lain yang dikuasakan olehnya.

\subsection{Pencatatan Dalam Buku Tanah Terhadap Hak Atas Tanah Yang Menjadi Objek Sengketa}

Dengan menggunakan teknik interpretasi gramatikal terhadap ketentuan pasal 126 ayat (1) dan (2) Peraturan Kepala BPN No. 8 tahun 2012, penulis berpendapat bahwa pencatatan dalam buku tanah atau 
dalam

prakteknya

disebut

pemblokiran sertipikat adalah suatu tindakan administrasi yang dilakukan oleh Kantor pertanahan untuk mencegah terjadinya perubahan data pendaftaran tanah dalam buku tanah atau terjadinya peralihan hak atas tanah yang dijadikan obyek gugatan di Pengadilan, atas permohonan pihak yang berkepentingan.

Adanya pencatatan dalam buku tanah atau karena adanya sengketa hukum hak atas tanah yang bermula dari pengaduan suatu pihak yang berisi keberatan-keberatan dan tuntutan hak atas tanah baik terhadap status tanah, prioritas maupun kepemilikannya dengan harapan dapat memperoleh penyelesaian secara admnistrasi sesuai dengan ketentuan peraturan yang berlaku. Selama adanya catatan dalam buku tanah atau blokir sertipikat tersebut, maka menurut PP No. 24 Tahun 1997 ditentukan bahwa :

1. PPAT dapat menolak membuat akta apabila obyek perbuatan hukum yang bersangkutan sedang dalam sengketa mengenai data fisik dan data yuridisnya sebagaimana ditentukan dalam Pasal 39 ayat (1) huruf f PP No. 24 tahun 1997.

2. Kantor pertanahan wajib menolak melakukan pendaftaran peralihan dan pembebanan hak apabila hak atas tanah yang bersangkutan merupakan obyek sengketa di Pengadilan sebagaimana ditentukan dalam Pasal 45 ayat (1) huruf e PP No. 24 tahun 1997.

Sengketa yang sering terjadi dalam praktek dan selama ini masih banyak yang belum dapat diselesaikan mengenai peralihan hak atas tanah berdasarkan jual beli adalah karena ternyata pada saat pembuatan dan penandatanganan akta jual beli telah lunas dibuktikan dengan kwitansi lunas atau bukti transfer. Namun setelah akta dibuat, penjual ternyata mengembalikan uang pembayaran kepada pembeli dikarenakan permasalahan antara kedua pihak. Pihak penjual tidak memiliki itikad baik sehingga jual beli dianggap belum lunas. Penjual kemudian melakukan pemblokiran sertipikat atau karena objek jual beli merupakan jaminan utang-piutang namun tidak dibebankan hak tanggungan.Dengan adanya pemblokiran sertipikat ketika akta jual beli telah dibuat, dari 4 (empat) tahapan proses pendaftaran peralihan hak atas tanah, PPAT telah melakukan 3 tahap yaitu tahap persiapan akta, tahap pembuatan akta dan tahap pendaftaran peralihan hak atas tanah. Namun baru pada tahapan ketiga telah terjadi pemblokiran sertipikat sehingga dalam tahap ketiga ini belum dapat dilanjutkan sampai pada adanya pencabutan blokir atau gugurnya blokir sertipikat.

4.3 Akibat Hukum Terhadap Pendaftaran Peralihan Hak Atas Tanah Yang Menjadi Objek Sengketa Terkait Adanya Pencatatan Dalam Buku Tanah

Pengembalian akta, sertipikat serta dokumen-dokumen karena adanya penolakan pendaftaran oleh Kantor Pertanahan berdasarkan Pasal 45 PP No. 24 tahun 1997 memberikan akibat hukum terhadap akta jual beli yang dibuat PPAT. Sengketa terhadap 
hak atas tanah terjadi pada saat pendaftaran peralihan hak atas tanah setelah akta jual beli telah dibuat. Sengketa terjadi karena ternyata pembayaran belum lunas ataupun objek jual beli masih menjadi objek utang-piutang namun tidak dibebani hak tanggungan. Padahal PPAT telah membuat akta sesuai prosedur yang benar, yaitu sebelumnya telah melakukan pemeriksaan kesesuaian data dalam sertipikat dengan data dalam buku tanah pada kantor pertanahan yang ternyata tidak ada sengketa dan tidak ada pembebanan hak tanggungan.

Sebagai akta otentik, akta PPAT sebagai alat bukti yang mempunyai kekuatan pembuktian yang sempurna selama terjadi pemblokiran sertipikat sebagai akibat dari adanya sengketa akan tetap otentik karena akta PPAT tersebut telah dibuat sesuai dengan prosedur atau tata cara yang ditetapkan sehingga tidak ada cacat yuridis yang mengakibatkan akta otentik batal, dapat dibatalkan atau batal demi hukum. Akibat hukum terhadap akta PPAT selama terjadi pemblokiran adalah akta tetap otentik

Jual beli tanpa dibuktikan dengan akta PPAT tidak akan memperoleh sertipikat, walaupun jual belinya sah menurut hukum. Peralihan hak atas tanah telah sah terjadi pada saat syarat materiil dan syarat formil terpenuhi dan sesuai juga dengan syarat-syarat sahnya perjanjian dan syarat sahnya jual beli walaupun belum didaftarkan pada kantor Pertanahan. Pendaftaran ini bersifat administratif untuk dapat memberikan jaminan kepastian dan perlindungan hukum. Terkait dengan adanya sengketa hak atas tanah ini, BPN dapat memfasilitasi sebagai mediator dengan menyelesaikan secara musyawarah. Sengketa hak atas tanah dapat saja diselesaikan tanpa dibawa pengadilan, dengan penandatangan akta perdamaian sehingga blokir dapat dicabut oleh pemohon blokir dan akta jual beli beserta dokumendokumennya dapat didaftarkan kembali kepada kantor pertanahan.

Dikaitkan dengan teori

kewenangan dan teori kebsahan,akibat hukum dari pendaftaran peralihan hak atas tanah yang menjadi objek sengketa adalah kantor pertanahan menolak melakukan pendaftaran peralihan hak atas tanah sehingga dilakukan pengembalian berkas kepada PPAT. Akta jual beli tetap sah karena akta dibuat oleh PPAT berdasarkan kewenangannya secara atribusi yaitu membuat akta otentik sebagai alat bukti telah dilakukannya peralihan hak atas tanah, akta telah dibuat sesuai tata cara dan prosedur yang benar yaitu memenuhi syarat materiil dan syarat formil sehingga tidak ada kekurangan atau cacat yuridis sesuai dengan peraturan perundang-undangan yang berlaku.

V. TANGGUNG JAWAB PPAT TERHADAP PENDAFTARAN PERALIHAN HAK ATAS TANAH YANG MENJADI OBJEK SENGKETA

\subsection{Kewenangan dan Kewajiban PPAT Dalam Pendaftaran Peralihan Hak Atas Tanah Yang Menjadi Objek Sengketa}

Embrio lahirnya PPAT tidak terlepas dengan kegiatan pendaftaran tanah di Indonesia sebagaimana 
dirumuskan dalam Pasal 19 ayat (1)

UUPA, yang menyatakan bahwa

"Untuk menjamin kepastian hukum

oleh pemerintah diadakan pendaftaran tanah di seluruh wilayah Indonesia menurut ketentuan-ketentuan yang diatur dalam peraturan pemerintah." Dengan adanya pendaftaran tanah kemudian diatur mengenai jabatan PPAT. Pasal 19 PP No. 24 Tahun 1997 menentukan bahwa setiap perjanjian yang bermaksud mengalihkan hak atas tanah, memberikan suatu hak baru atas tanah, menggadaikan tanah atau meminjam uang dengan suatu akta yang dibuat oleh dan dihadapan Pejabat yang ditunjuk oleh Menteri Agraria. Akta tersebut bentuknya telah ditetapkan. Kedudukan hukum PPAT merupakan perpanjangan tangan BPN dalam pembuatan akta tanah yang merupakan syarat konstitutif yang merupakan salah satu subsistem dalam pendaftarannya pada Kantor pertanahan.

Dengan menggunakan teknik analisis interpretasi gramatikal terhadap ketentuan Pasal 2 PP No. 37 tahun 1998 mengenai tugas pokok PPAT, maka PPAT bertugas pokok melaksanakan sebagian kegiatan pendaftaran tanah yaitu dengan membuat akta sebagai bukti telah dilakukannya perbuatan hukum tertentu mengenai hak atas tanah atau hak milik atas satuan rumah susun yang kemudian menjadi dasar pendaftaran perubahan data pendaftaran tanah yang terjadi karena perbuatan hukum tersebut. Selain memiliki kewenangan, PPAT juga memiliki kewajiban yang tidak terlepas dari kewenangannya tersebut. PPAT tidak hanya sebatas memiliki kewenangan membuat akta, namun wajib untuk melakukan persiapan pembuatan akta yaitu pengecekan sertipikat, melaksanakan pendaftaran hak atas tanah yang ditentukan selambat-lambatnya 7 (tujuh) hari sejak ditandatanganinya akta sampai sertipikat telah dibaliknama dan diterbitkan oleh kantor pertanahan kemuadian PPAT menyerahkan sertipikat tersebut kepada yang berhak untuk itu.

Pada saat terjadi pemblokiran sertipikat, kantor Pertanahan berdasarkan Pasal 45 PP No. 24 Tahun 1997 dapat menolak melakukan pendaftaran dan adanya pengembalian semua dokumen terkait. Mengenai pengembalian berkas ini, apabila ditelaah dengan menggunakan teknik interpretasi gramatikal, maka pengembalian berkas adalah pengembalian berkas kepada PPAT sebagai pelaksana pendaftaran peralihan hak atas tanah. Selama terjadi pemblokiran, baik akta, sertipikat beserta dokumen-dokumennya berada pada kantor PPAT. Dalam proses peralihan hak atas tanah, PPAT wajib untuk bertindak sebagai penengah (middle man), selain sebagai pejabat umum yang membuat akta otentik sebagai alat bukti yang kuat untuk membuktikan terjadinya peralihan hak atas tanah. PPAT sebagai penengah artinya bahwa harus bertindak berdasarkan kepentingan kedua belah pihak, bukan berarti menguntungkan diri sendiri atau bahkan salah satu pihak saja selama terjadinya pemblokiran sertipikat ini. PPAT dalam menjalankan tugasnya ini tidak boleh berpihak kepada salah satu pihak karena profesi PPAT, sama seperti Notaris adalah profesi yang mandiri.

\subsection{Tanggung Jawab PPAT Terhadap Pendaftaran Peralihan Hak Atas Tanah yang Menjadi Objek Sengketa}

PPAT harus menjaga sertipikat dan dokumen bersangkutan yang dikembalikan oleh kantor pertanahan akibat adanya penolakan pendaftaran dengan baik dan tidak boleh sembarangan menyerahkan sertipikat tersebut kepada salah satu pihak. Terkait adanya 
sengketa antara penjual dan pembeli ataupun dengan pihak ketiga, walaupun telah terjadi peralihan hak atas tanah dari penjual ke pembeli berdasarkan akta jual beli namun belum adanya balik nama sertipikat dari nama penjual menjadi nama pembeli maka PPAT tidak berhak menyerahkan sertipikat kepada pembeli selama pemblokiran tersebut. Berdasarkan ketentuan Pasal 31 ayat (3) PP No. 24 tahun 1997, PPAT hanya boleh menyerahkan sertifikat kepada pihak yang namanya tercantum dalam buku tanah yang bersangkutan sebagai pemegang hak atau kepada pihak lain yang dikuasakan olehnya.

PPAT berkewajiban dan bertanggung jawab untuk menyimpan sertipikat sampai pemblokiran dicabut karena sengketa dapat diselesaikan dengan musyawarah atau sampai adanya penyitaan oleh pengadilan terhadap hak atas tanah tersebut karena menjadi objek gugatan di Pengadilan. Terlebih lagi karena PPAT menerima bayaran untuk membuat akta peralihan hak atas tanah, dengan mana menerima dan memproses sertipikat tanah sampai proses balik nama selesai tersebut ke Kantor pertanahan merupakan kewajiban dan prosedur dari tahapan pendaftaran peralihan hak atas tanah termasuk didalamnya pembuatan akta yang menjadi tugas PPAT bersangkutan. Tanggung jawab PPAT terkait dengan kewenangannya, meliputi :

1. Tanggung jawab perdata PPAT;

2. Tanggung jawab pidana PPAT;

3. Tanggung jawab administratif PPAT;

4. Tanggung jawab moral PPAT berdasarkan kode etik PPAT.

Berdasarkan teori pertanggungjawaban yang digunakan adalah teori fautes personalles, secara perdata PPAT bertanggung jawab secara individu atau pribadi atas pebuatannya dalam pelaksanaannya jabatan baik terhadap akta yang dibuatnya. Sedangkan terhadap penyimpanan sertipikat selama hak atas tanah menjadi objek sengketa dalam hal adanya pemblokiran sertipikat maka yang digunakan adalah teori fautes de services yaitu PPAT bertanggungjawab berdasarkan jabatan yang diberikan kepadanya. PPAT wajib memberikan pelayanan dan bertanggung jawab untuk menyimpan sertipikat dan dokumen-dokumen yang dikembalikan oleh kantor pertanahan selama adanya pemblokiran sertipikat. Pada saat pemblokiran belum jelas siapa yang berhak atas sertipikat walaupun telah terjadi peralihan hak atas tanah namun ternyata ada sengketa hak atas tanah.

Mengenai tanggung jawab PPAT diatur dalam Pasal 55 Peraturan Kepala BPN No. 1 tahun 2006, PPAT bertanggungjawab secara pribadi atas pelaksanaan tugas dan jabatannya dalam setiap pembuatan akta. Jika dianalisis menggunakan analisis interpretasi gramatikal, dalam Pasal 55 Peraturan Kepala BPN No. 1 tahun 2006, mengatur secara keseluruhan mengenai tanggung jawab PPAT terhadap segala tindakannya yang berlandaskan jabatannya dalam proses pembuatan akta, pasal tersebut menyatakan bahwa PPAT bertanggungjawab secara pribadi. Dalam hal ini PPAT tidak hanya bertanggung jawab secara pribadi terhadap akta yang dibuatnya, namun juga bertanggung jawab berdasarkan jabatannya untuk memberikan pelayanan terhadap dokumen-dokumen termasuk sertipikat yang digunakan dalam proses pendaftaran peralihan hak atas tanah sampai pada proses pendaftaran peralihan hak atas tanah selesai dan sertipikat diserahkan kepada pemegang hak yang berhak.

Kewenangan dan kewajiban PPAT adalah dari tahapan PPAT menerima sertipikat terkait proses persiapan pembuatan akta sampai pada proses telah dikeluarkannya sertipikat dari Kantor Pertanahan yang telah selesai. PPAT berwenang dan berkewajiban dalam proses 
persiapan pembuatan akta sampai pada sertipikat telah selesai diterbitkan maka PPAT memiliki tanggung jawab untuk itu. Apabila adanya kerugian dari salah satu pihak terkait dengan adanya pemblokiran sertipikat karena hak atas tanah menjadi objek sengketa, maka PPAT tidak dapat dituntut untuk bertanggungjawab kecuali para pihak dapat membuktikannya.

PPAT telah melakukan tahapan peralihan hak atas tanah yaitu melakukan dengan tata cara atau prosedur yang berlaku. PPAT wajib untuk menerapkan prinsip ketelitian dan kehati-hatian pada saat menerima keterangan penghadap dan mengkonstatir keinginan pada penghadap tujuannya adalah agar salah satu diantara para pihak ataupun pihak lainnya tidak merasa dirugikan. Selain terhadap akta yang dibuatnya, PPAT bertanggung jawab secara moral memberikan pelayanan berupa menyimpan dan mejaga sertipikat tidak sembarangan menyerahkan kepada salah satu pihak karena proses balik nama belum selesai. Untuk hal itu, PPAT tidak berhak untuk meminta pembayaran atau biaya terkait kewajibannya untuk menyimpan sertipikat beserta dokumen yang dikembalikan oleh kantor pertanahan. Apabila PPAT meminta biaya tambahan maka PPAT dapat dikenakan sanksi administratif atau sanksi moral berdasarkan kode etik PPAT. PPAT sebagai pihak penengah wajib menjaga kepentingan kedua pihak sampai proses pendaftaran peralihan hak atas tanah telah selesai.

Mengenai pembahasan tanggung jawab PPAT terhadap pendaftaran peralihan hak atas tanah ini selain menggunakan teori pertanggungjawaban juga menggunakan teori kepastian hukum. PPAT berdasarkan kewenangan dan kewajibannya memiliki tanggung jawab untuk menjamin adanya kepastian hukum terhadap akta yang dibuatnya sebagai alat bukti telah dilakukannya perbuatan-perbuatan hukum tertentu mengenai hak atas tanah yang digunakan sebagai dasar. Pendaftaran ini dalam tunjuan untuk memberikan jaminan kepastian dan perlindungan hukum terhadap pemegang hak atas tanah yang baru.

\section{PENUTUP}

\section{1 Simpulan}

1. Akibat hukum terhadap pendaftaran peralihan hak atas tanah yang menjadi objek sengketa terkait adanya pencatatan dalam buku tanah adalah adanya penolakan pendaftaran hak atas tanah oleh kantor pertanahan setempat sehingga tidak dapat dilakukan pendaftaran atau perubahan data pertanahan selama pemblokiran. Berdasarkan Pasal 45 PP No. 24 tahun 1997, kantor pertanahan menolak melakukan pendaftaran dengan mengembalikan berkas berupa akta, sertipikat dan dokumendokumen terkait kepada PPAT yang bersangkutan sebagai pelaksana pendaftaran peralihan hak atas tanah. Akibat hukum terhadap akta jual beli yang dikembalikan tetap menjadi akta otentik dan dapat kembali digunakan sebagai dasar pendaftaran apabila pemblokiran telah dicabut oleh pemohonnya.

2. PPAT memiliki tanggung jawab pribadi atas pelaksanaan tugas dan jabatannya dalam setiap pembuatan akta sebagaimana ditentukan dalam Pasal 55 Peraturan Kepala BPN No. 1 Tahun 2006. Selain dalam pembuatan akta, PPAT juga 


memiliki tanggung jawab dari
tahap persiapan pemuatan akta
yaitu melakukan pengecekan
sertipikat pada buku tanah,
pembuatan akta, pendaftaran
peralihan hak atas tanah sampai
pada penerbitan sertipikat dan
menyampaikan sertipikat kepada
pemegang hak atas tanah yang
tertera namanya di sertipikat.
PPAT juga bertanggung jawab
berdasarkan jabatannya dalam
menyimpan akta, sertipikat beserta
dokumen yang bersangkutan pada
saat dikembalikan oleh kantor
Pertanahan ketika adanya
penolakan pendaftaran oleh kantor
pertanahan. PPAT tidak dapat
dituntut apabila telah melakukan
kewenangan dan kewajibannya
sesuai dengan prosedur yang
berlaku. PPAT wajib sebagai pihak
penengah menyimpan dokumen-
dokumen yang dikembalikan
sampai pada saat dilakukan
pentaan oleh pengadilan atau
pelan plokir oleh pemohon

PPAT tidak berhak untuk meminta pembayaran tambahan.

\subsection{Saran-saran \\ 1. Kepada Pemerintah \\ Diharapkan agar segara dibuat undang-undang khusus mengenai pertanahan untuk melengkapi UUPA.} Selain itu agar dapat membuat peraturan-perundang-undangan khusus mengenai jabatan PPAT. Diharapkan juga agar pengaturan mengenai kewenangan dan kewajiban PPAT menjadi lebih jelas sehingga tidak menimbulkan permasalahan yang merugikan profesi PPAT di kemudian hari.

\section{Kepada Profesi PPAT}

Diharapkan agar PPAT menjalankan tugasnya sesuai dengan peraturan perundangundangan yang berlaku dan kode etik PPAT sehingga mampu memberikan pelayanan dan kenyamanan pada setiap penghadap. PPAT agar selalu menjadi pihak penengah yaitu tidak mementingkan salah satu pihak namun mampu bersikap adil dan menjaga kepentingan kedua belah pihak dan mampu melaksanakan kewenangan serta kewajibannya sampai proses sehingga kegiatan pendaftaran tanah dapat terlaksana dengan baik.

\section{DAFTAR PUSTAKA}

\section{Buku-Buku :}

Adjie, Habib, 2008, Hukum Notaris Indonesia, Tafsir Tematik Terhadap UU No. 30 Tahun 2004 tentang Jabatan Notaris, Refika Aditama, Bandung.

Harsono, Boedi, 1978, Beberapa Analisis Tentang Hukum Agraria II, Esa Studi Klub, Jakarta.

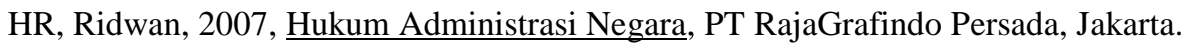

Ibrahim, Johnny, 2005, Teori dan Metodologi Penelitian Hukum Normatif, Bayumedia, Surabaya.

Sidharta, 2000, Hukum Perlindungan Konsumen, Grasindo, Jakarta.

Marzuki, Peter Mahmud, 2008, Pengantar Ilmu Hukum, Kencana Predana Media Group, Jakarta.

Murad, Rusmadi, 1991, Penyelesaian Sengketa Hukum Atas Tanah, Alumni, Bandung. 
Rifai, Ahmad, 2010, Penemuan Hukum Oleh Hakim Dalam Perspektif Hukum Progresif, Sinar Grafika, Jakarta.

Santoso, Urip, 2010, Pendaftaran dan Peralihan Hak atas Tanah, Kencana Predana Media Group, Jakarta.

Soekanto, Soerjono dan Sri Mamudji, 2007, Penelitian Hukum Normatif : Suatu Tinjauan Singkat, PT. Raja Grafindo Persada, Jakarta.

Sunggono, Bambang, 2010, Metodelogi Penelitian Hukum, Rajawali Pers, Jakarta.

Syarief, Elza, 2014, Menuntaskan Sengketa Tanah Melalui Pengadilan Khusus Pertanahan, Cetakan Kedua, PT. Gramedia, Jakarta.

\section{Artikel Internet :}

Ardiansyah, 2012, "Tolak Ukur Keabsahan Tindak Pemerintahan dan Keputusan Tata Usaha Negara", http://ardianlovenajlalita.wordpress.com/tolok-ukur-keabsahan-tindak-pemerintahan-dan-keputusantata-usaha-negara/, diakses pada tanggal 05 Maret 2014.

Boedi Djatmiko Hadiatmodjo, 2010, “Tanah dan Hukum Tanah”, http://sertifikattanah.blogspot.com/, diakses pada tanggal 21 Pebruari 2014.

\section{Peraturan Perundang-undangan :}

Undang-Undang Dasar Negara Republik Indonesia 1945.

Kitab Undang-undang Hukum Perdata.

Undang-Undang Republik Indonesia Nomor 5 Tahun 1960 tentang Peraturan Dasar Pokok-Pokok Agraria, Lembaran Negara Republik Indonesia Tahun 1960 Nomor 104, Tambahan Lembaran Negara Nomor 2043.

Peraturan Pemerintah Republik Indonesia Nomor 24 Tahun 1997 tentang Pendaftaran Tanah, Lembaran Negara Republik Indonesia Tahun 1997 Nomor 59, Tambahan Lembaran Negara Nomor 3696.

Peraturan Pemerintah Republik Indonesia Nomor 37 tahun 1998 tentang Peraturan Pejabat Pembuat Akta Tanah, Lembaran Negara Republik Indonesia Tahun 1998 Nomor 52.

Peraturan Presiden Republik Indonesia Nomor 10 tahun 2006 tentang Badan Pertanahan Nasional.

Peraturan Kepala Badan Pertanahan Nasional Nomor 1 Tahun 2006 Tentang Ketentuan Pelaksanaan Peraturan Pemerintah No. 37 Tahun 1998 Tentang Peraturan Jabatan Pejabat Pembuat Akta Tanah.

Peraturan Kepala Badan Pertanahan Nasional Nomor 8 Tahun 2012 tentang Perubahan Atas Peraturan Menteri Agraria/Kepala Badan Pertanahan Nasional Nomor 3 Tahun 1997 tentang Ketentuan Pelaksanaan Peraturan Pemerintah Nomor 24 Tahun 1997 tentang Pendaftaran Tanah.

$* * * * *$ 